[NA]

\title{
Late Cenozoic basaltic volcanism around the Taiwan Strait, SE China: Product of lithosphere-asthenosphere interaction during continental extension
}

\author{
Sun-Lin Chung ${ }^{\mathrm{a}, \mathrm{b}}$, Shen-su Sun ${ }^{\mathrm{c}}$, Kan Tu ${ }^{\mathrm{d}, \alpha}$, Cheng-Hong Chen ${ }^{\mathrm{a}}$ and Chi-yu Lee ${ }^{\mathrm{a}}$ \\ 'Department of Geology, National Taiwan University, 245 Choushan Road, Taipei 10770, Taiwan, ROC \\ ${ }^{\circ} G e ́ o s c i e n c e s ~ R e n n e s$, Université de Rennes 1, F-35042 Rennes Cedex, France \\ 'Australian Geological Survey Organisation, P.O. Box 378, Canberra ACT 2601, Australia \\ ${ }^{d}$ Department of Geological Sciences, University of Illinois, P.O. Box 4348, Chicago, IL 60680, USA
}

(Received March 1, 1993; revised and accepted June 23, 1993)

\begin{abstract}
Late Cenozoic intraplate basaltic volcanism in SE China and Taiwan occurred as a result of lithospheric extension related to the opening of the South China Sea. It was gradually terminated by the compression which propagated westwards from the arc-continent collision in Taiwan since $\sim 12 \mathrm{Ma}$ ago. The basalts show a spatial variation in chemical composition. Their alkalinity, degree of silica undersaturation and abundance of incompatible elements increase whilst $\mathrm{Pb}$ isotopic ratios decrease $\left({ }^{206} \mathrm{~Pb} /{ }^{204} \mathrm{~Pb}\right.$ from 19.0 to 18.2$)$ progressively away from a NE-trending extension axis in the western Taiwan Strait. Abundant tholeiites were emplaced near the axial zone whereas alkali basalts, basanites and nephelinites took place further away from this axis. Overall, the basalts have $\mathrm{Sr}-\mathrm{Nd}-\mathrm{Pb}$ isotopic systematics similar to those of seamount basalts in the South China Sea which are characterized by a Dupal-type Pb isotopic anomaly. Based on geochemical constraints from the basalts, depth estimates for mantle xenoliths and regional geophysical data, a passive extension model is proposed for the geodynamic evolution of this region. It suggests greatest lithosphere thinning during the Miocene beneath the axial zone. The lithospheric mantle was thermo-mechanically eroded by convective upwelling of the asthenosphere, a process that raised the lithospheric geotherm and resulted in a plum-pudding-type convecting mantle. The spatial chemical and isotopic variation in the basalts can be explained by different degrees of decompression melting of this convecting mantle, corresponding to a change in lithosphere thickness, compounded by various contributions from the continental lithospheric mantle (CLM) -derived plum component. This model, which involves continental extension followed by magma generation via lithosphere-asthenosphere interaction, should be applicable to other areas of Cenozoic rift magmatism around the South China Sea and in the eastern Eurasian continental margin.
\end{abstract}

\section{Introduction}

Extension of lithosphere is generally considered to play an important role in the generation of continental intraplate volcanism (e.g., McKenzie and Bickle, 1988). During extension different types of basaltic magmas can form, under various $P-T$ conditions, from the convective asthenosphere and/or the thermally activated continental lithospheric man-

\footnotetext{
${ }^{\alpha}$ Present address: Dames \& Moore, 1701 Golf Road, Suite 1000, Rolling Meadows, IL 60008, USA.
}

tle (CLM). Integrated information on geochronology, petrology and geochemistry of intraplate basalts and mantle xenoliths contained therein can thus provide constraints regarding the tectonic history of tensional areas as well as the chemical characteristics of magma sources located in the asthenosphere and the lithospheric mantle. Some extensioninduced interactions between these two mantle reservoirs, such as upwelling of the asthenosphere and thermo-mechanical erosion of the basal CLM (e.g., Davis, 1991; KRISP, 1991), may also be reflected in the chemical and iso- 
topic compositions of the magmas (Wendlandt and Morgan, 1982; Perry et al., 1988; Tatsumi and Kimura, 1991 ).

Cenozoic continental extension around the Taiwan Strait has resulted in basaltic volcanism in the Fujian-Taiwan region (Fig. 1). This extension is generally accepted to be related to the opening of the South China Sea which, in turn, most likely resulted from the India-Eurasia collision (Tapponnier et al., 1986). These basalts usually contain mantle xenoliths (garnet and spinel peridotites) and display chemical and isotopic characteristics similar to the seamount basalts in the South China Sea (Tu et al., 1992). They hence can provide important information for studying the relationships between intraplate volcanism, mantle dynamics and lithosphere rifting not only in this region but also in the South China Sea and possibly the rifted eastern Eurasian continental margin. In this paper, we summarize published and our unpublished chemical and isotopic data of the late Cenozoic basalts from Fujian Province, Penghu Islands (in the Taiwan Strait) and northwestern Taiwan. A spatial chemical and isotopic variation in the basalts is rather well demonstrated. Likewise, as compared to the seamount basalts in the South China Sea, characteristics of their mantle sources can be constrained. Based on integration of these geochemical data with $P-T$ estimates for the mantle xenoliths and available geophysical information, we propose a tectonomagmatic model to account for the generation of the basalts. This model, which emphasizes lithosphere-asthenosphere interaction

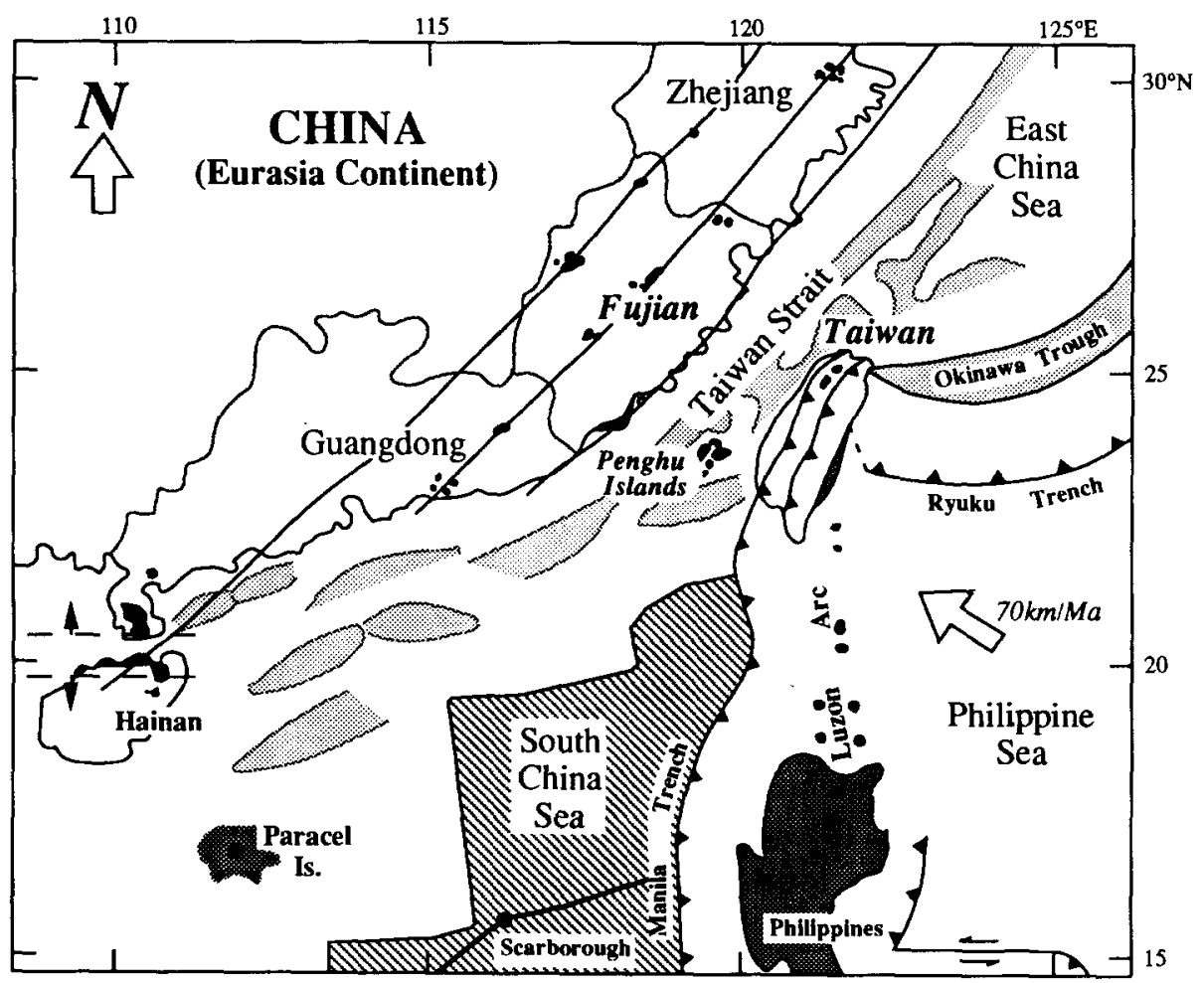

Fig. 1. Generalized map for geotectonic framework and outcrops of the late Cenozoic basalts (black areas) in SE China. Note that three volcanic belts in Fujian Province spread along a NE-trending fault system. Extension-induced sedimentary basins in the South China continental margin (S.C. Sun, 1985; Ru and Piggot, 1986) are indicated by dotted regions. In the South China Sea, the oceanic crust and the extinct spreading center are shown. Localities of certain circum-SCS basalts discussed in this paper (e.g., Hainan Island, Paracel Island and Scarborough seamounts) are also shown for reference. 
during extension, should be applicable to the magma generation in other basalt provinces engaged in passive continental rifting.

\section{Geotectonic background}

It is generally agreed that southeast Asia is an assembly of allochthonous continental terranes originally fragmented from Gondwanaland. Their amalgamation and accretion were largely completed during the early Mesozoic, but the processes appear to be very complex and contentious (Metcalfe, 1990). South China, as a member of these terranes, may have behaved as a coherent block during its northward drifting since the late Paleozoic (Lin et al., 1985; Metcalfe, 1990). Until the late Cretaceous, its margin was marked by extensive subduction-related rhyolitic volcanism cou- pled with intrusions of syntectic granitoids (BGMR, 1985; Jahn et al., 1990). Then, the tectonic environment drastically changed from convergent to dilational as indicated by the emplacement of intraplate basalts. According to Tapponnier et al. (1986), Cenozoic tectonic evolution of this area is closely related to the India-Eurasia collision since at least $50 \mathrm{Ma}$ ago (Klootwijk et al., 1992). The South China Sea was opened as a pull-apart basin induced by "extrusion tectonics" resulting from this collision. The tensional forces which have formed numerous NE-trending sedimentary basins surrounding the South China Sea (Ru and Pigott, 1986) may have propagated northeastwards to the Fujian-Taiwan region of SE China (Fig. 1).

Based on a paleostress study on the Penghu Islands, Angelier et al. (1990) noted that ex-

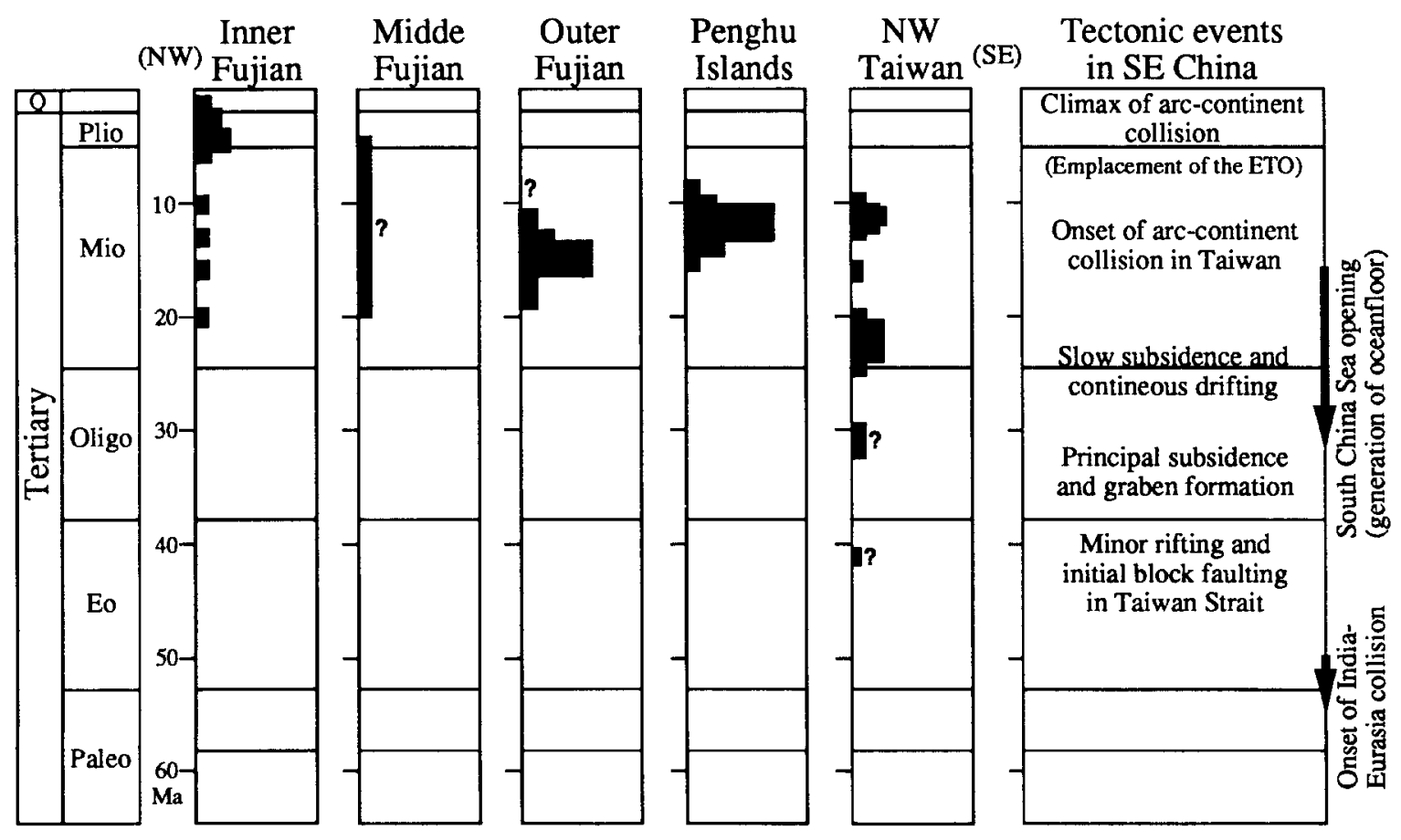

Fig. 2. Age histogram of the Cenozoic basalts and the major tectonic events in SE China. The basaltic volcanism was most active in the Miocene. A principal rifting stage with major subsidence and graben formation took place in the Oligocene, contemporaneously with the onset of the South China Sea opening but preceding the main phase of volcanism. Age data are from Zhou et al. (1988), Fan and Hooper (1991), and J.B. Zhang and Chen (1992) for the Fujian volcanics, and CH. Chen (1990), Juang (1992) and C.-y. Lee and C-H. Chen (unpublished data, 1993) for Penghu and NW Taiwan volcanics. Question marks indicate possible durations of volcanic activities estimated from ages of the associated sedimentary strata without radiometric dating. 


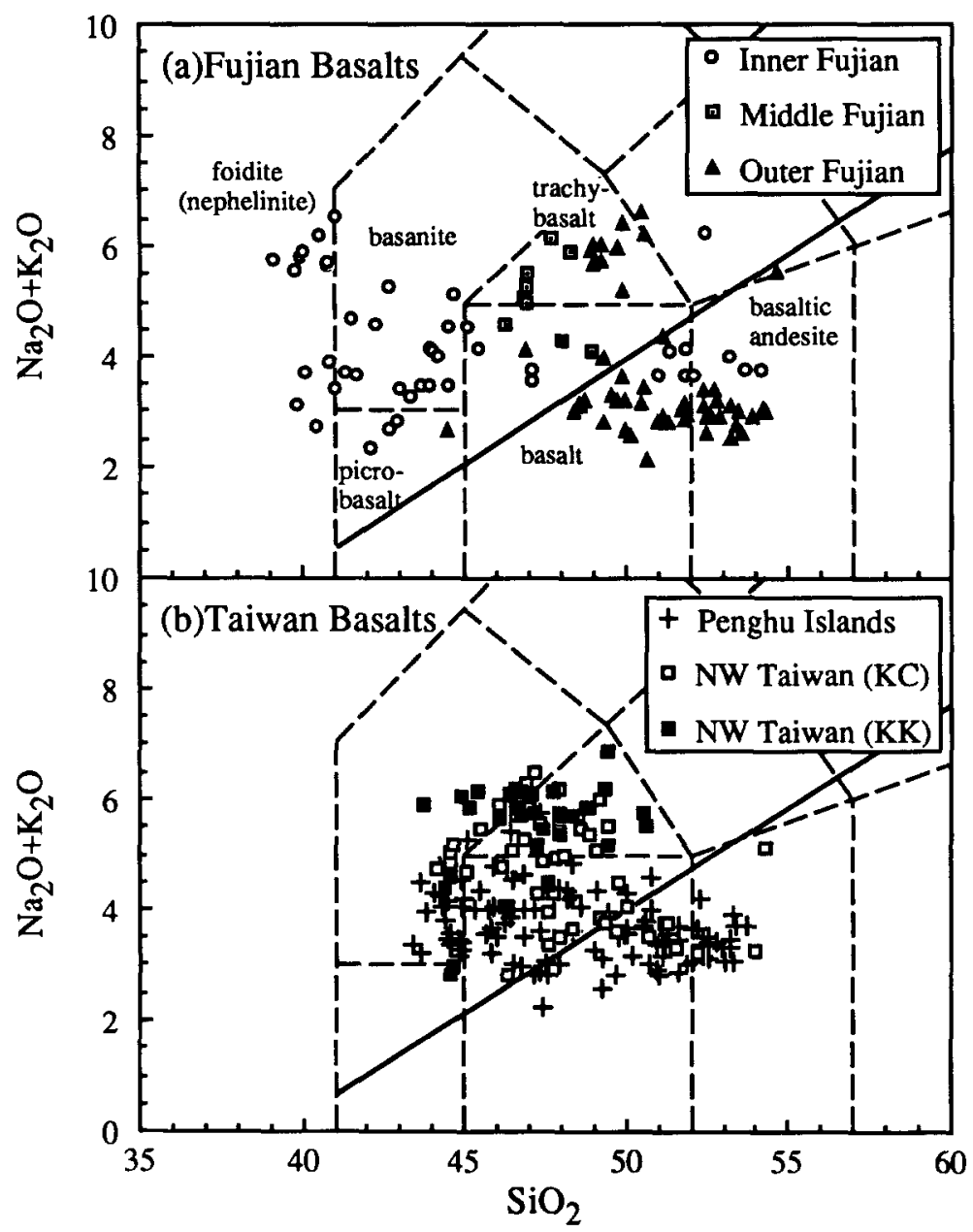

Fig. 3. Total alkalis vs. $\mathrm{SiO}_{2}$ plots for the SE China basalts from: (a) Fujian Province; and (b) Penghu Islands and NW Taiwan. For simplicity, basaltic members are generally called as tholeiite and alkali basalt according to the thick line suggested by MacDonald and Katsura (1964). The alkali-rich member with $\mathrm{SiO}_{2}<45 \%$ is further classified as basanite and nephelinite following Le Maitre (1989), whose classification scheme is shown. Two stages of basalts in NW Taiwan, namely, the Kungkuan $(K K)$ and the Kuanhsi-Chutung $(K C)$ with peak durations of 23-20 and 13-9 Ma, respectively, are plotted. Data are from W.H. Sun and Lai (1980), Qi and Zhang (1985), Zhao (1990), and Fan and Hooper (1991) for the Fujian volcanics and J.C. Chen (1973), C-H. Chen et al. (1987), Chung et al. (1994) and C.-y. Lee (unpublished data, 1993) for the basalts from Penghu Islands and NW Taiwan.

tension around the Taiwan Strait followed seafloor spreading in the South China Sea. Late Cenozoic basaltic volcanism in SE China, in view of its geotectonic setting and the absence of mantle plume activity (cf. Tu et al., 1992), is a consequence of this passive extension. The time sequence (Fig. 2) demonstrates that peak volcanism was preceded by a main rifting stage. The rifting began in the late Eocene and caused a major subsidence with graben formation in the early Oligocene (Teng et al., 1991). The magmatism, although commenced since the Paleogene, was most active in the Miocene ( 23-8 Ma).

Taiwan is an island created by the arc-continent collision between the Luzon volcanic arc and the Eurasian continent (Fig. 1). This collision, which began in the late Miocene $(\sim 12$ $\mathrm{Ma}$ ) and reached a climax in the last $3 \mathrm{Ma}$ (Chi et al., 1981; Teng, 1990), changed the tectonic 
TABLE 1

Representative chemical compoistions of the dominant basalts in SE China

\begin{tabular}{|c|c|c|c|c|c|c|c|c|}
\hline & \multicolumn{2}{|c|}{ Innter Fujian } & \multirow{2}{*}{$\begin{array}{l}\text { M. Fujian } \\
\text { MQ-I } \\
\text { AB }\end{array}$} & \multirow{2}{*}{$\begin{array}{l}\text { O. Fujian } \\
\text { FN-2-I } \\
\text { TH }\end{array}$} & \multicolumn{2}{|c|}{ Penghu Islands } & \multicolumn{2}{|c|}{ NW Taiwan } \\
\hline & $\begin{array}{l}\text { SL-15 } \\
\text { NE }\end{array}$ & $\begin{array}{l}\text { MD-2 } \\
\text { BA }\end{array}$ & & & $\begin{array}{l}\text { PH-89 } \\
\text { TH }\end{array}$ & $\begin{array}{l}\mathrm{PH}-96 \\
\mathrm{AB}\end{array}$ & $\begin{array}{l}\mathrm{TN}-4 \\
\mathrm{AB}\end{array}$ & $\begin{array}{l}\mathrm{L}-302 \\
\mathrm{BA}\end{array}$ \\
\hline \multicolumn{9}{|c|}{ (wt.\%): } \\
\hline $\mathrm{SiO}_{2}$ & 40.75 & 43.33 & 48.68 & 50.79 & 51.64 & 44.87 & 46.18 & 42.26 \\
\hline $\mathrm{TiO}_{2}$ & 3.56 & 3.12 & 2.27 & 1.47 & 1.86 & 2.14 & 2.83 & 3.21 \\
\hline $\mathrm{Al}_{2} \mathrm{O}_{3}$ & 11.36 & 9.23 & 13.20 & 15.25 & 14.21 & 12.79 & 13.72 & 12.49 \\
\hline $\mathrm{Fe}_{2} \mathrm{O}_{3}{ }^{\mathrm{a}}$ & 5.60 & 1.40 & 1.13 & 1.17 & 11.60 & 12.62 & 12.46 & 12.56 \\
\hline $\mathrm{FeO}$ & 8.14 & 11.31 & 9.20 & 9.51 & & & & \\
\hline $\mathrm{MnO}$ & 0.18 & 0.20 & 0.16 & 0.17 & 0.15 & 0.19 & 0.20 & 0.18 \\
\hline $\mathrm{MgO}$ & 11.13 & 15.80 & 10.82 & 9.55 & 7.33 & 11.48 & 9.99 & 11.40 \\
\hline $\mathrm{CaO}$ & 11.11 & 11.55 & 9.40 & 9.32 & 9.49 & 9.57 & 9.21 & 9.21 \\
\hline $\mathrm{Na}_{2} \mathrm{O}$ & 3.38 & 1.66 & 2.13 & 2.32 & 2.66 & 2.38 & 3.61 & 3.80 \\
\hline $\mathrm{K}_{2} \mathrm{O}$ & 2.33 & 1.04 & 2.20 & 0.25 & 0.31 & 1.42 & 1.14 & 0.49 \\
\hline $\mathrm{P}_{2} \mathrm{O}_{5}$ & 1.09 & 1.37 & 0.79 & 0.19 & 0.24 & 0.72 & 0.67 & 0.90 \\
\hline \multicolumn{9}{|c|}{ (ppm): } \\
\hline $\mathrm{Ba}$ & & 843 & 742 & 141 & 153 & 500 & 883 & 825 \\
\hline $\mathrm{Cr}$ & & 541 & 297 & 174 & 208 & 449 & 236 & 454 \\
\hline Hf & & & & & 3.1 & 5.4 & 6.8 & 6.6 \\
\hline $\mathrm{Nb}$ & & 118 & 75 & 17 & 18 & 61 & 82 & 70 \\
\hline $\mathrm{Ni}$ & & 451 & 285 & 160 & 161 & 333 & 225 & 327 \\
\hline Rb & & 62 & 56 & 4 & 6 & 47 & 12 & 9 \\
\hline Sc & & 16 & 22 & 21 & 25 & 24 & 21 & 23 \\
\hline $\mathrm{Sr}$ & & 1,448 & 1,020 & 314 & 306 & 738 & 749 & 795 \\
\hline $\mathrm{Ta}$ & & & & & 1.2 & 3.8 & 4.8 & 4.3 \\
\hline Th & & & & & 1.7 & 6.9 & 6.0 & 7.0 \\
\hline $\mathbf{U}$ & & & & & 0.4 & 1.5 & 1.3 & 1.6 \\
\hline V & & 201 & 168 & 167 & 188 & 218 & 195 & 251 \\
\hline $\mathrm{Y}$ & & 37 & 28 & 16 & 22 & 30 & 31 & 32 \\
\hline $\mathrm{Zr}$ & & 382 & 291 & 114 & 114 & 225 & 300 & 277 \\
\hline $\mathrm{La}$ & & 100 & 54 & 12 & 12.7 & 51.3 & 52.8 & 61.9 \\
\hline $\mathrm{Ce}$ & & 180 & 96 & 22 & 25.2 & 97.8 & 103 & 116 \\
\hline $\mathrm{Nd}$ & & 82 & 46 & 13 & 16.2 & 45.0 & 51.8 & 54.9 \\
\hline $\mathrm{Sm}$ & & 13 & 8.6 & 3.3 & 4.4 & 8.4 & 9.0 & 10.2 \\
\hline $\mathrm{Eu}$ & & 4.2 & 2.7 & 1.3 & 1.5 & 2.5 & 2.9 & 3.2 \\
\hline $\mathrm{Gd}$ & & 11 & 7.8 & 3.7 & & & & \\
\hline $\mathrm{Tb}$ & & 1.5 & 1.2 & 0.56 & 0.70 & 1.2 & 1.2 & 1.3 \\
\hline Dy & & 6.4 & 5.2 & 2.8 & & & & \\
\hline Ho & & 1.1 & 1.0 & 0.56 & & & & \\
\hline $\mathrm{Yb}$ & & 1.4 & 1.5 & 0.98 & 1.70 & 1.8 & 2.1 & 2.1 \\
\hline $\mathbf{L u}$ & & 0.19 & 0.26 & 0.13 & 0.27 & 0.28 & 0.29 & 0.31 \\
\hline
\end{tabular}

$\mathrm{NE}=$ nephelinite; $\mathrm{BA}=$ basanite; $\mathrm{AB}=$ alkali basalt; $\mathrm{TH}=$ tholeiite. Data sources: W.H. Sun and Lai (1980), Fan and Hooper (1991) and G.C. Fan (unpublished data, 1993) for Fujian samples; C-H. Chen (1990) and Chung et al. (1994) for Penghu and Taiwan samples.

Total $\mathrm{Fe}$ as $\mathrm{Fe}_{2} \mathrm{O}_{3}$ for Taiwan samples.

setting from a dilational to a compressional regime and gradually terminated the intraplate volcanism. Although the Taiwan Strait is tectonically undeformed, basaltic volcanism in the
Penghu Islands ceased $\sim 8 \mathrm{Ma}$ ago (Juang, 1992; C.-y. Lee and C.-H. Chen, unpublished data, 1992). This termination indicates westward propagation of the compressional regime 

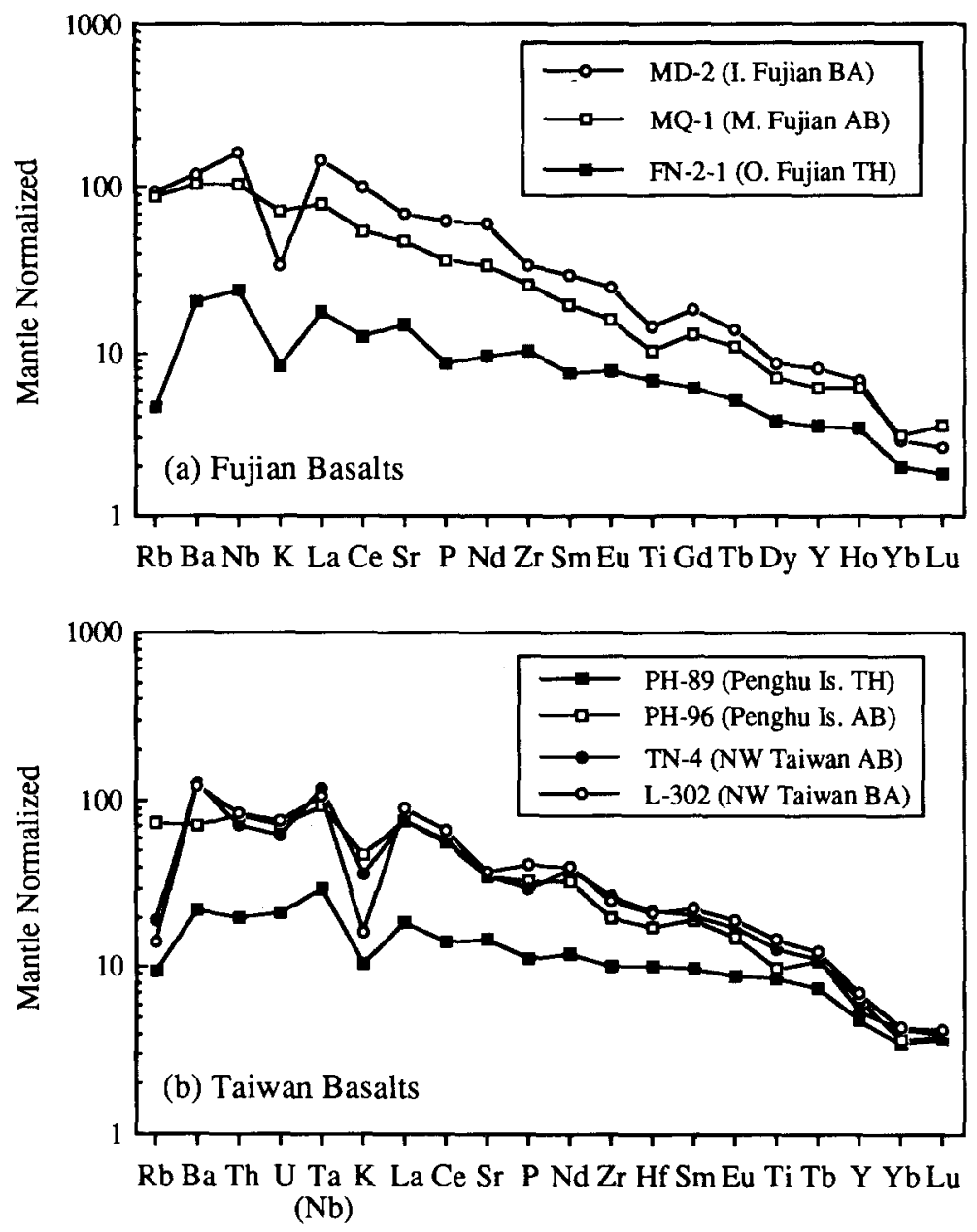

Fig. 4. Primitive-mantle-normalized diagrams of the representative SE China basalts. For data values and sources, see Table 1. The normalizing values are from S.-s. Sun and McDonough (1989).

which may have acted as a forerunner to the arc-continent collision. However, further to the northwest, $\sim 350 \mathrm{~km}$ away from the Penghu Islands, volcanism in the Inner Fujian area lasted until the late Quaternary ( $\sim 0.7 \mathrm{Ma}$; J.B. Zhang and Chen, 1992).

\section{Chemical and isotopic characteristics of basalts in SE China}

Late Cenozoic basalts are widely dispersed in SE China. In the Fujian Province, three volcanic belts, namely, the Outer, Middle and In- ner Fujian belts (from the east to the west), can be recognized (Fig. 1). They extend along a NE-trending deep fault system (W.H. Sun and Lai, 1980), probably corresponding to the trans-lithospheric Tan-Lu fault which has a close relationship to Cenozoic basaltic volcanism in north and northeast China (Peng et al., 1986; Zhou et al., 1988; Fan and Hooper, 1991). To the east of Fujian Province, abundant basaltic flows were emplaced simultaneously on Penghu Islands and in NW Taiwan (Figs. 1 and 2). Moreover, according to seismostratigraphic and drilling studies (S.C. Sun, 1985), many magmatic lenses exist in the Ter- 


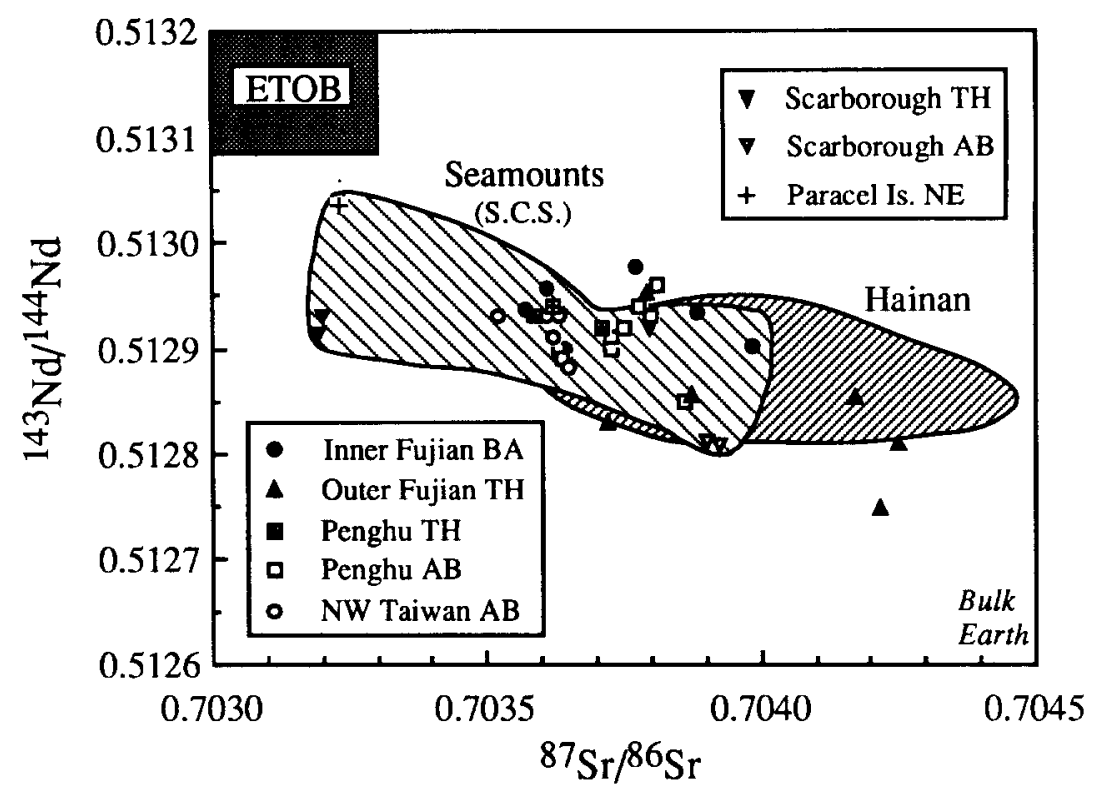

Fig. $5 .{ }^{87} \mathrm{Sr} /{ }^{86} \mathrm{Sr}$ vs. ${ }^{143} \mathrm{Nd} /{ }^{144} \mathrm{Nd}$ diagram for the SE China basalts. Data are from Basu et al. (1991), J.B. Zhang and Chen (1992), and K. Tu et al. (unpublished data, 1992) for the Fujian samples and Chung et al. (1994) for Penghu and NW Taiwan samples. No Sr and Nd isotopic data are available for the volcanics in Middle Fujian. Fields for the basalts from seamounts in Hainan Island (Tu et al., 1991) and the South China Sea (Tu et al., 1992) are shown for comparison. Field for the basalts of East Taiwan Ophiolite (Jahn, 1986; Chung and Sun, 1992) is also constructed, assuming ${ }^{87} \mathrm{Sr} /{ }^{86} \mathrm{Sr}$ ratios $<0.7033$.

tiary sedimentary basins within the Taiwan Strait.

\subsection{Spatial variation in chemical composition}

W.H. Sun and Lai (1980) noted the existence of a spatial variation in basaltic composition which becomes progressively more alkaline in areas away from the coast of Fujian Province. The dominant magma types change from tholeiite through alkali basalt to basanite and nephelinite from the Outer to Inner belts of the Fujian Province (Fig. 3a). This variation was incorrectly interpreted as a result of increasing depths of magma generation in relation to a northwestward subduction of the paleo-Pacific plate (W.H. Sun and Lai, 1980). They failed to recognize the OIB (ocean island basalt) -type geochemical characteristics in the
Fujian basalts (Table 1; Fig. 4a), which are consistent with the late Cenozoic intraplate basalts around the South China Sea (Tu et al., 1992).

On Penghu Islands, the volcanics are composed of alternating flows of tholeiites and alkali basalts (Fig. 3b). Their chemical compositions (Table 1) are similar to the Fujian basalts and show typical intraplate characteristics (Fig. 4b). Further to the east, alkali basalts and basanites (Table 1; Fig. 3b) occur predominantly in the Miocene sedimentary strata in NW Taiwan. They also display intraplate geochemical signatures (Fig. 4b). According to Suppe (1981), the Miocene strata hosting these basalts were originally situated $\sim 200 \mathrm{~km}$ to the southeast. As a result of the arc-continent collision, these strata have been deformed and transported via a northwestward thrust-related shortening to the presentday configuration . 


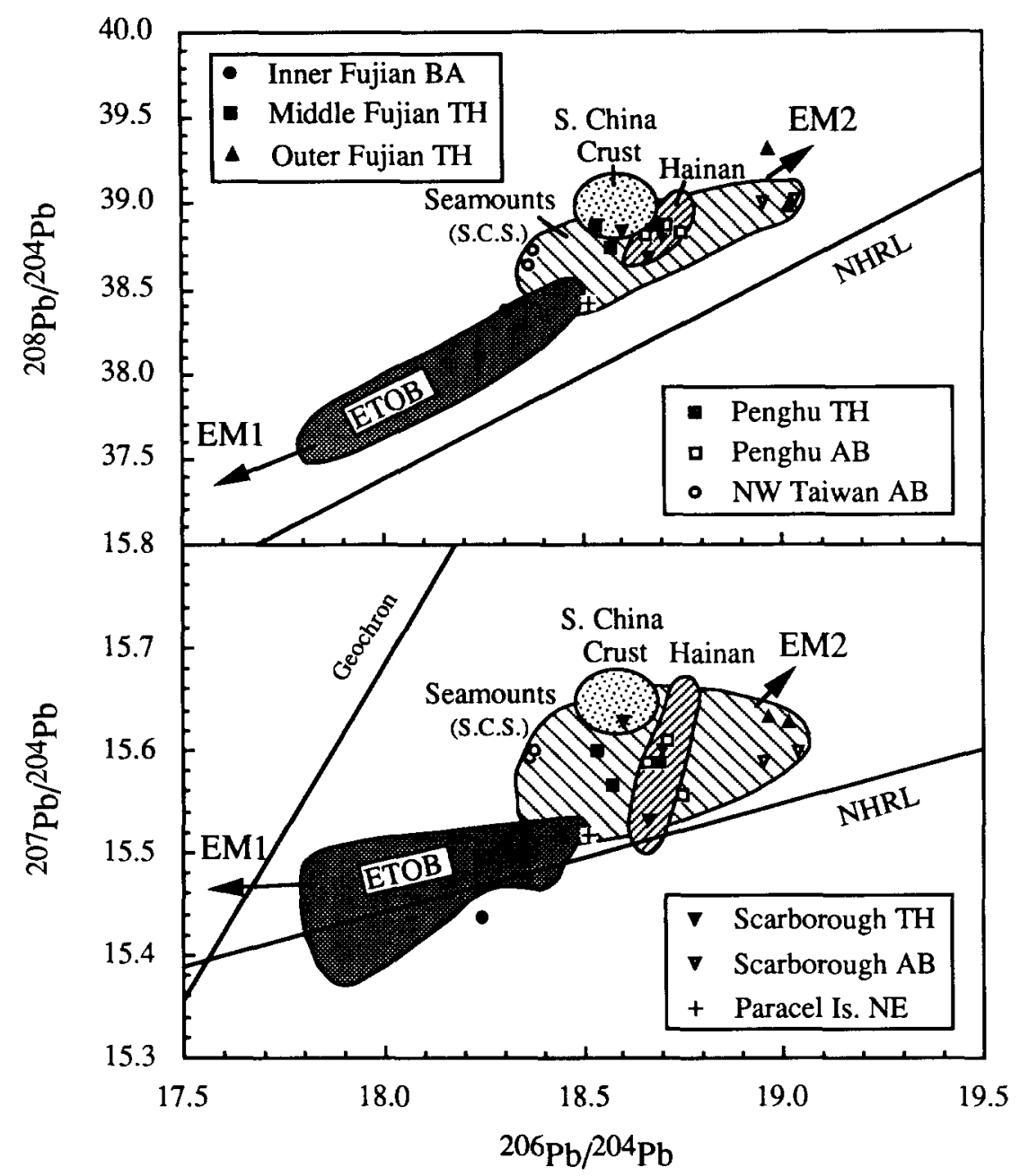

Fig. 6. Pb isotopic diagrams for the SE China basalts. Data are from S.-s. Sun (1980), Basu et al. (1991), and K. Tu et al. (unpublished data, 1992). Field for the South China continental crust is represented by the Paleozoic and Mesozoic granitoids in South China ( $\mathrm{Li}, 1988$ ) and the terrigenous sediments from the South China Sea (McDermott et al., 1993). $N H R L=$ Northern Hemisphere Reference Line (Hart, 1984). EM1 and EM2=enriched mantle types 1 and 2, respectively (Zindler and Hart, 1986).

\subsection{Isotope systematics}

The dominant basalts in SE China show a minor variation in $\mathrm{Sr}$ and $\mathrm{Nd}$ isotopic ratios (Fig. 5). The Inner Fujian basanites have somewhat higher ${ }^{143} \mathrm{Nd} /{ }^{144} \mathrm{Nd}$ ratios than the Outer Fujian tholeiites. The latter, moreover, appear to be rather scattered in the Sr-Nd isotopic diagram. All basalts from other belts plot in a more uniform manner. Most SE China data fall in the field of post-spreading sea- mount basalts in the South China Sea (Tu et al., 1992) and show similar $\mathrm{Sr}$ and $\mathrm{Nd}$ isotopic ratios to the basalts from Hainan Island (Tu et al., 1991). They all plot within the main OIB field (S.-s. Sun and McDonough, 1989) and share a common feature exhibiting distinct $\mathbf{S r}$ isotopic variation over a relatively small ${ }^{143} \mathrm{Nd} /{ }^{144} \mathrm{Nd}$ range. This similarity probably indicates a genetic correlation between these basalts and lends further support to the suggestion that extension around the Taiwan Strait 
was propagated from the opening of the South China Sea.

The limited amount of $\mathrm{Pb}$ isotopic data show a significant spatial variation (Fig. 6). The ${ }^{206} \mathrm{~Pb} /{ }^{204} \mathrm{~Pb}$ ratios increase from the Inner ( 18.2) through Middle ( 18.6) to Outer Fujian belts $(\sim 19.0)$, and then decrease towards Penghu Islands $(\sim 18.7)$ and NW Taiwan $(\sim 18.5)$. Except one ${ }^{207} \mathrm{~Pb} /{ }^{204} \mathrm{~Pb}$ data point of Inner Fujian basanite, all $\mathrm{Pb}$ isotopic data plot above the NRHL (Northern Hemisphere Reference Line; Hart, 1984). Their $\Delta^{208} \mathrm{~Pb}$ - and $\Delta^{207} \mathrm{~Pb}$-values (i.e. vertical deviations from the NHRL) vary from +41 to +83 and from +3.7 to +10 , respectively. Consistent with other circum-South China Sea (SCS) basalts (Tu et al., 1992), they constitute a trend subparallel to the NHRL in the ${ }^{208} \mathrm{~Pb} /{ }^{204} \mathrm{~Pb}$ vs. ${ }^{206} \mathrm{~Pb} /{ }^{204} \mathrm{~Pb}$ plots and display the Dupal-type $\mathrm{Pb}$ isotope signature commonly found in the southern hemisphere (Hart, 1984).

The tholeiites and alkali basalts in Penghu Islands are characterized by virtually indistinguishable isotopic ratios $\left({ }^{87} \mathrm{Sr} /{ }^{86} \mathrm{Sr} \approx 0.7037\right.$, $\epsilon_{\mathrm{Nd}} \approx+5$ and ${ }^{206} \mathrm{~Pb} /{ }^{204} \mathrm{~Pb} \approx 18.7$ ). This is similar to cases of the Reed Bank seamounts in the South China Sea (Tu et al., 1992) and the Loihi seamount, Hawaii, central Pacific (e.g., Staudigel et al., 1984), but in contrast with the isotopically heterogeneous Hainan Island basalts (Figs. 5 and 6) which also comprise tholeiites, alkali basalts and subordinate basanites (Tu et al., 1991).

\subsection{Other observations}

There are two more features in basalt chemistry deserving further attention:

(1) In addition to the principal types of basalts in each belt, some subordinate volcanics blur the spatial chemical and isotopic variation. These are transitional basalts and basaltic andesites with more evolved compositions $(\mathrm{MgO} \approx 5-6 \mathrm{wt} \%)$ in the Outer Fujian area as well as somewhat younger tholeiitic rocks in both NW Taiwan and the Inner Fujian area
(Fig. 3). They are more fractionated and have significantly lower $\mathrm{Nd}$ and higher $\mathrm{Sr}$ isotopic ratios (Zhao, 1990; Chung et al., 1994). In the Inner Fujian area, moreover, the tholeiitic basalts and basaltic andesites commonly have similar ${ }^{206} \mathrm{~Pb} /{ }^{204} \mathrm{~Pb}$ but higher ${ }^{207} \mathrm{~Pb} /{ }^{204} \mathrm{~Pb}$ ratios than the dominant basanites ( $\mathrm{Zhu}$ et al., 1992). These magmas could not have been derived from the convecting mantle without involvement of some shallow-level modifications including crustal contamination (Chung et al., 1994).

(2) Many SE China basalts show a potassium depletion in spidergrams (Fig. 4), a feature commonly observed in intraplate basalts worldwide. Some NW Taiwan basalts are strongly depleted in $\mathrm{K}$ and $\mathrm{Rb}$ and show abnormally high $\mathrm{Ba} / \mathrm{Rb}$ ratios up to $\sim 50-100$, when compared with the common $\mathrm{Ba} / \mathrm{Rb}$ value of $\sim 12$ for intraplate basalts (S.-s. Sun and McDonough, 1989). Similar depletions are known in some basalts from Hawaii and from the Newer Volcanics of Australia and are believed to result from subaerial weathering processes (e.g., Frey et al., 1991; Price et al., 1991). So far we follow this explanation for such depletions in the basalts studied here.

\section{Basalt generation through lithosphere- asthenosphere interaction}

\subsection{Constraints provided by basalt major elements}

Experimental studies have demonstrated that partial melts from a mantle peridotite should be more silica-saturated at higher temperatures and lower pressures of melting (cf. Falloon et al., 1988). This concept provides a rough estimate of depth of magma segregation if the compositions of primary basaltic magmas can be known. The most primitive SE China basalts (i.e., $\mathrm{Mg} \# \geqslant 64$; Fan and Hooper, 1991; Chung et al., 1994) from each belt were selected for this purpose to estimate their pri- 
mary magma compositions and segregation depths, following a model proposed by Nohda et al. (1991). The basic assumptions of this model are as follows: (1) the primary magmas fractionate only olivine; (2) the $\mathrm{Fe}-\mathrm{Mg}$ partition coefficient between olivine and magma is 0.3 ; $(3)$ the composition of olivine in mantle is $\mathrm{Fo}_{90}$; and (4) the $\mathrm{Fe}^{2+} /\left(\mathrm{Fe}^{2+}+\mathrm{Fe}^{3+}\right)$ ratio of magma is constant at 0.85 . The compositions of primary magmas were then calculated by adding olivine step by step back to the natural basalts. According to the isobaric composition trends for partial melts of the mantle peridotite, the pressures of magma segregation can be estimated.

The results (Table 2) show that near-axis Outer Fujian tholeiites were generated at the lowest pressures ( $\sim 15 \mathrm{kbar}$ ), whereas Inner Fujian nephelinites and basanites as well as NW Taiwan basanites were generated at the highest pressures ( $\geqslant 25-30$ kbar). This information may be indicative of the structure of the upper mantle, probably reflecting the boundary of the lithosphere and asthenosphere (Nohda et al., 1991). Hence the scenario of spatial variation in basalt chemistry would suggest a symmetrically extended makeup around the Taiwan Strait. In addition, as the dominant basalts in each belt show rather uniform isotopic compositions, it seems reasonable to consider the convecting mantle as their major common source. We thus propose that the uppermost portion of the convecting mantle, as commonly suggested by geophysical evidence (Davis, 1991; KRISP, 1991 ), can act as a source for partial melts during continental rifting. The depth information provided by $\mathrm{SE}$ China basalt chemistry reflects a mantle doming event beneath the Taiwan Strait at the main stage of intraplate volcanism.

TABLE 2

Summary of characteristics of the late Cenozic basalts and their mantle xenoliths in SE China

\begin{tabular}{|c|c|c|c|c|c|}
\hline Volcanic belt & Inner Fujian & Middle Fujian & Outer Fujian & Penghu Islands & NW Taiwan \\
\hline Dominant magma types & NE, BA & $\mathrm{AB}$ & TH & $\mathrm{TH}, \mathrm{AB}$ & $\mathrm{AB}, \mathrm{BA}$ \\
\hline Age of eruption & $20-0.7 \mathrm{Ma}$ & mid-Miocene & $19-11(?) \mathrm{Ma}$ & $16-8 \mathrm{Ma}$ & $23-9 \mathrm{Ma}$ \\
\hline${ }^{206} \mathrm{~Pb} /{ }^{204} \mathrm{~Pb}$ & $\sim 18.3$ & $\sim 18.6$ & $\sim 19.0$ & $\sim 18.7$ & $\sim 18.5$ \\
\hline Magma segregation $P^{\mathbf{a}}$ (kbar) & $>30$ & $\sim 25$ & $\sim 15$ & $\begin{array}{l}\sim 15(\mathrm{TH}) \\
\quad 20-25(\mathrm{AB})\end{array}$ & $25-30$ \\
\hline Major xenolith types & $\begin{array}{l}\text { Sp LHERZ, } \\
\text { Gt LHERZ }\end{array}$ & $\begin{array}{c}\text { Sp HARZ, Sp } \\
\text { LHERZ, Gt } \\
\text { LHERZ }\end{array}$ & $\begin{array}{r}\text { Sp LHERZ, } \\
\text { Sp HARZ }\end{array}$ & $\begin{array}{l}\text { Sp HARZ, Sp } \\
\text { LHERZ }\end{array}$ & $\begin{array}{l}\text { Sp HARZ, Sp } \\
\text { LHERZ, (Gt } \\
\text { LHERZ?) }\end{array}$ \\
\hline Max. $T$ for xenoliths ${ }^{b}\left({ }^{\circ} \mathrm{C}\right)$ & $1,200-1,250$ & $\sim 1,250$ & $\sim 1,100$ & 1,250 & $\sim 1,000(?)$ \\
\hline Max. $P$ for xenoliths ${ }^{c}$ (kbar) & $25-30$ & $\sim 25$ & $\sim 15$ & $20-25$ & $\sim 17(?)$ \\
\hline Min. CL thickness (km) & $90-100$ & $\sim 80$ & $\sim 50$ & $\sim 80$ & $\sim 80-90^{\mathrm{d}}$ \\
\hline
\end{tabular}

$\mathrm{Sp}=$ spinel; $\mathrm{Gt}=$ garnet; $\mathrm{LHERZ}=$ lherzolite; HARZ=harzburgite; $\mathrm{NE}=$ nephelinite; $\mathrm{BA}=$ basanite; $\mathrm{AB}=$ alkali basat; TH = tholeiite; $\mathrm{CL}=$ continental lithosphere. Data sources: Basalts: S.-a. Sun (1980), W.H. Sun and Lai (1980), Qi and Zhang (1985), C-H. Chen et al. (1987, 1989), R.Y. Zhang and Cong (1987), C-H. Chen (1990), Zhao (1990), Fan and Hooper (1991), Zhang and Cheng (1992), Chung et al. (1994) and K. Tu et al. (unpublished data, 1992). Xenoliths: R.Y. Zhang and Cong (1987), Fan and Hooper (1989), Chung (1990) and S.L. Chung (unpublished data, 1992).

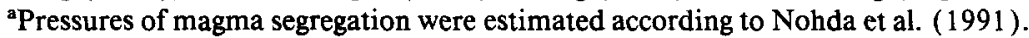

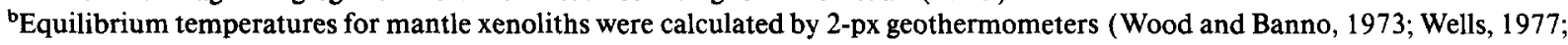
Brey and Kohler, 1990).

'Equilibrium pressures for mantle xenoliths were calculated by using olivine geobarometers (Kohler and Brey, 1989; Brey and Kohler, 1990) for spinel-bearing lithologies and by using gt-px geobarometers (Nickel and Green, 1985; Brey and Kohler, 1990) for garnet-bearing lithologies.

${ }^{\text {d} A l t h o u g h ~ n o ~ h i g h ~} P-T$ mantle xenoliths have been found yet in NW Taiwan, perhaps partly due to restricted exposure and tectonic deformation of the hosting strata, the inferred minimum thickness of continental lithosphere can be estimated by depth information from the dominant basalts. 


\subsection{Constraints provided by mantle xenoliths}

Basalts in SE China commonly contain a variety of deep-seated xenoliths. Late Miocene paleogeotherms, constructed by using mineral data of mantle xenoliths from the Inner Fujian belt and Penghu Islands (R.Y. Zhang and Cong, 1987; Chung, 1990; Chung et al., 1994), show elevated geothermal gradients within the lithosphere. They are similar to those of SE Australia (O'Reilly and Griffin, 1985) and NW Spitsbergen (Amundsen et al., 1987), respectively. At the same depth, the ambient temperature beneath the Inner Fujian belt was systematically $\sim 50-100^{\circ} \mathrm{C}$ lower than beneath the Outer Fujian belt and Penghu Islands (Chung, 1990). This is consistent with the dominant occurrence of tholeiites in the near-axis region, as a result of mantle doming during the middle to late Miocene around the Taiwan Strait.

$P-T$ estimates for mantle xenoliths can further indicate the greatest entrainment depths in each volcanic belt (Table 2 ). They are generally consistent with the depth estimation for magma separation discussed in Section 4.1 and can also provide constraints for variation of the lithospheric thickness. The inferred thickness of lithosphere is thinnest in the Outer Fujian belt $(\sim 50 \mathrm{~km})$, whereas deeper high-temperature mantle xenoliths (with equilibrium temperatures $\geqslant 1200^{\circ} \mathrm{C}$ and pressures $\geqslant 25 \mathrm{kbar}$; Chung, 1990) occur to the east and west. If we accept the convecting asthenosphere has a normal potential temperature of $1280^{\circ} \mathrm{C}$ (McKenzie and Bickle, 1988), the presence of high $P-T$ xenoliths (some even yield temperatures of $\sim 1250^{\circ} \mathrm{C}$; Table 2) indicates that these xenoliths may originate from the deeper part of the CLM. Although a sampling artifact may not be ruled out, the absence of high $P-T$ xenoliths in Outer Fujian basalts seems to support the suggestion that beneath the axial zone the base of lithosphere had been thermo-mechanically eroded.

\subsection{Constraints provided by geophysical data}

Although the extensional setting in SE China ceased as a result of the arc-continent collision (Suppe, 1981; Teng, 1990), geophysical data from the tectonically undeformed regions, such as the Taiwan Strait and Fujian Province, may still offer useful information on lithospheric thickness, thermal condition and paleostructure of the SE China lithosphere.

Continental extension provinces are usually characterized by the existence of a regional gravity low and reduced seismic velocities in the uppermost mantle (Keller et al., 1991; KRISP, 1991). This is generally considered to be a reflection of thermal elevation and partial melting probably resulting from mantle doming. In the Taiwan Strait, a low $v_{\mathrm{P}}(7.6-7.8 \mathrm{~km}$ $\mathrm{s}^{-1}$ ) has been reported in the uppermost mantle, $\sim 0.2-0.5 \mathrm{~km} \mathrm{~s}^{-1}$ slower than that beneath the Inner Fujian area (Liao et al., 1987). Moreover, the gravity data (Wang, 1987; SCSIO-FOI, 1989) reveal a symmetric pattern along the western Taiwan Strait. They both may reflect a relict memory of the Tertiary extensional framework in this region.

Further information concerning this "memory" includes: (1) crustal thickness estimated by geophysical methods decreases gradually from the Inner Fujian belt $(\geqslant 36 \mathrm{~km})$ to the western Taiwan Strait $(\sim 25-27 \mathrm{~km})$ (C.C. Liu and Yen, 1975; Ma, 1987); and (2) geophysical modelling studies (Ma, 1987; Wan et al., 1989) suggest that the present lithospheric thickness in Fujian Province decreases towards the coastline $(\sim 120 \mathrm{~km}$ in the Inner Fujian and $80 \mathrm{~km}$ in the Outer Fujian areas). These "geophysical" lithospheric thicknesses are somewhat greater than the "geochemical" thicknesses estimated from the basalts and mantle xenoliths. It may imply that, if both depth estimates are accurate, a thickening process through underplating of materials to the continental lithosphere has occurred in postMiocene time. This could be a response of regional cooling due to the arc-continent collision. 


\section{Magma sources for SE China basalts}

The OIB-type chemical and isotopic characteristics of basalts in SE China indicate that they are mainly derived from the upper mantle without much crustal contamination. These volcanics, including certain tholeiites in the Outer Fujian belt, usually contain mantle xenoliths (Table 2 ). In each belt the dominant basalts show quite uniform isotopic compositions similar to those of the SCS seamount basalts (Figs. 5 and 6 ). The latter, erupted mostly on oceanic lithosphere, have been considered to originate directly from the convecting mantle (Tu et al., 1992). Another compelling piece of evidence negating crustal contamination emerges from the $\mathrm{Pb}$ isotopic ratios. The $\mathrm{Pb}$ isotopic trend of SE China basalts can hardly be explained by mixing of any mantle sources with the South China continental crust (Fig. $6)$. The Outer Fujian tholeiites, resembling some SCS seamount basalts (e.g., alkali basalts from the Scarborough seamounts), show significantly higher ${ }^{206} \mathrm{~Pb} /{ }^{204} \mathrm{~Pb}$ ratios but plot away from the field of continental crust, which is constructed in terms of Paleozoic and Mesozoic granitoids from south China $(\mathrm{Li}, 1988)$ and terrigenous sediments from the South China Sea (McDermott et al., 1993). In the Pb isotopic plots, the Hainan basalts display a high-angle trend (Fig. 6). The effect of crustal contamination, however, can be ruled out based on the same arguments (Tu et al., 1991).

We hence conclude that the chemical and isotopic characteristics of SE China basalts overwhelmingly reflect the mantle signature. Two mantle sources, namely, the asthenosphere and the CLM, could have been involved in magma generation. The isotopic affinity between the SE China basalts and the SCS seamount basalts seems to favor an asthenospheric origin. However, this is contradicted by a significant distinction between these two suites of magmas. Seamount volcanics are commonly marked by a coherent variation between chemical and isotopic composi- tions (Zindler et al., 1984). In general, the more incompatible-element-enriched seamount basalts have lower $\mathrm{Nd}$ and higher $\mathrm{Sr}$ and $\mathrm{Pb}$ isotopic ratios. This appears to be the rule, not only for the Scarborough seamount basalts (Tu et al., 1992), but also for the basalts in neighbouring marginal basins such as the Philippine Sea (Hickey-Vargas, 1991). In SE China, by contrast, Outer Fujian tholeiites, rather than the chemically more enriched Inner Fujian basanites, display lower Nd and higher $\mathrm{Sr}$ and $\mathrm{Pb}$ isotopic ratios (Figs. 5 and $6)$. This paradoxical feature cannot be interpreted by a simple melting of the asthenospheric source. The CLM contribution, therefore, is considered to have played an important role in the basalt generation.

Even the enriched chemical and isotopic characteristics of the South China asthenospheric mantle, as observed in the SCS seamount basalts, are not "inherent" but should be inherited from the continental lithosphere (Chung and Sun, 1992; Tu et al., 1992). Chung and Sun (1992) proposed a "plum-pudding" -type convecting mantle model to explain the secular chemical and isotopic change in basalts from the mid-ocean region of the South China Sea. They suggested that this mantle source was produced by thermo-mechanical erosion of the CLM during opening of the South China Sea. The East Taiwan Ophiolite (ETO) is considered as rock association generated in the SCS mid-ocean axis region by the end of its spreading ( $\sim 15 \mathrm{Ma}$ of age). MORB (mid-ocean ridge basalt) -type basalts of the East Taiwan Ophiolite hence are representative of the asthenospheric matrix (i.e. the "pudding"). Extinction of the sea-floor spreading resulted in a gradual cooling environment in the South China Sea basin. The Scarborough seamounts straddling the extinct spreading axis were then emplaced by OIB-type basalts, varying from tholeiites $(\sim 14-10 \mathrm{Ma})$ to alkali basalts $(\sim 3.5 \mathrm{Ma})$, due to decreasing degrees of melting. Chung and Sun (1992) suggested that the 
enriched "plum" component may be preferentially melted under lower degrees of melting, as indicated by the Scarborough alkali basalts which display the "plum" signatures with higher $\mathrm{Sr}$ and $\mathrm{Pb}$ and lower $\mathrm{Nd}$ isotopic ratios (Figs. 5 and 6).

However, we note that this enriched "plum" component has a rather limited areal distribution, perhaps not beyond the region defined by the SCS oceanic plate (Fig. 1). A nephelinite in Paracel Island, located on the continental margin close to the continent-ocean plate boundary in the South China Sea, exhibits distinctly lower $\mathrm{Pb}$ and higher $\mathrm{Nd}$ isotopic ratios (Figs. 5 and 6) than the Scarborough seamount basalts (Tu et al., 1992). Moreover, it has isotopic compositions similar to those of the Inner Fujian basanites which overlap the field of ETO basalts. This feature reflects not only the horizontal mantle heterogeneity in the South China Sea region but also a recent occurrence of the "plum" component. It seems that the plums, localized beneath the oceanic lithosphere, have still avoided homogenization by the mantle convection.

There are different ways for generation, growth and modification of the CLM. South China continental crust is generally Proterozoic in age ( $\mathrm{Li}, 1988$; Jahn et al., 1990). As in other well-studied extensional areas (e.g., eastern Australia and western U.S.A.), intraplate metasomatic and subduction-related processes are likely two major agents for modifying continental lithosphere since its formation (cf. S.-s Sun et al., 1989; Menzies et al., 1991). Many recent petrological studies on mantle xenoliths reveal that the SE China CLM has been heterogeneously metasomatized. Hydrous phases such as amphibole and phlogopite occur either interstitially in some type-1 lherzolite xenoliths, or as veins of composite xenoliths (C-H. Chen et al., 1987; R.Y. Zhang and Cong, 1987; Chung, 1990; Tatsumoto et al., 1992; S.Y. O'Reilly, pers. commun., 1992). Limited isotopic data have been reported for the type- 1 mantle xenoliths from SE China
(Zhou and O'Nions, 1986; Menzies et al., 1992; Tatsumoto et al., 1992). They overall show depleted nature with low $\mathrm{Sr}$ and high $\mathrm{Nd}$ isotopic ratios. However, one spinel harzburgite demonstrates enriched isotopic signature with $\epsilon_{\mathrm{Nd}} \approx-1$ (Zhou and O'Nions, 1986) and many $\mathrm{Pb}$ isotopic data plot above the NHRL pointing to EM2 (Tatsumoto et al., 1992). In addition, mineral phases of the garnet lherzolite xenoliths from the Inner Fujian belt are also marked by a broad ${ }^{87} \mathrm{Sr} /{ }^{86} \mathrm{Sr}$ range for rather limited Nd isotopic ratios (Zhou and O'Nions, 1986; Tatsumoto et al., 1992). In this sense they resemble the $\mathrm{Sr}-\mathrm{Nd}$ systematics of the basalts. It is reasonable to assume that metasomatically enriched components should be present in the SE China CLM. These components could have been derived from its Gondwana connection by either ancient subduction processes or OIB-type plume-related magmatism (both EM1 and EM2). They may have also resulted from the prevailing Mesozoic subduction/accretion activities (EM2) along the South China continental margin. The latter process has been supported by recent ion microprobe data for the mantle xenoliths ( $M$. Zhang et al., 1992). These shallow mantle reservoirs could have been stretched, activated and thermally eroded by the Cenozoic rifting around the South China Sea and may be the source of the Dupal-type $\mathrm{Pb}$ isotopic signature observed in the basalts.

We further note that all ETO basalts, including those with the most depleted $\mathrm{Pb}$ isotope compositions, show elevated ${ }^{208} \mathrm{~Pb} /{ }^{204} \mathrm{~Pb}$ ratios pointing toward EM1 (Fig. 6), similar to the Central Indian Ocean Ridge basalts (Mahoney et al., 1989). Although a convective transport of the Dupal isotopic anomaly from the southern hemisphere by entrapment in subduction zones (Hickey-Vargas, 1991) may be possible, Chung and Sun (1992) argued that this ancient component could have been added from the CLM during opening of the South China Sea. Another possibility is the influence (invasion?) of the Indian Ocean-type mantle 
source to the convecting mantle in SE Asia. This could have been accomplished by multiple fragmentation and amalgamation processes of the Gondwana-derived microcontinents in this region, coupled by the simultaneous northward moving of the Indian Ocean plate.

\section{A tectonomagmatic model for SE China basalts}

In the following we present a new petrogenetic model with the understanding that some uncertainties might be inherited. They include: (1) evolution (formation, growth, reduction and modification) and chemical characteristics of the SE China continental lithosphere; (2) effect of extension mechanism on the lithosphere-asthenosphere interaction; (3) mechanism of decompression melting (e.g., dehydration melting or dry melting; fractional melting or batch melting); and (4) origin of the Dupal-like $\mathrm{Pb}$ isotopic anomaly in the northern hemisphere.

Based on the constraints discussed in the former two sections, we propose a lithospheric extension model to account for the late Cenozoic intraplate magmatism in SE China: NWSE trending rifting has resulted in lithosphere thinning and asthenosphere doming with an axis along the western Taiwan Strait (Fig. 7). The tensional environment may have reactivated old trans-lithospheric faults and initiated propagating cracks through the continental lithosphere. This could induce the intrusion of initial partial melts and act as an agent for advectively transporting heat upwards to raise the ambient temperature of the lithosphere. It was then followed by a progressive erosion of the basal CLM through multiple thermo-mechanical processes accompanying convective upwelling of the asthenosphere. Consequently, beneath the axial region, the lithosphere was gradually replaced from below by a "plumpudding" -type convecting mantle which mixed material from the CLM (the "plums") with the asthenospheric matrix (the "pudding").

Differences in depth of melt segregation, responding to a change of the lithospheric thickness (Fig. 7), created the spatial chemical variations in the basalts. Abundant tholeiites were generated at shallower depths from the convecting mantle in the near-axis zone (Outer Fujian belt) by larger degrees of melting with a dominant contribution of the metasomatized (hydrous) plums. It is well known that presence of water can greatly lower the solidus temperature of peridotite and drastically change the composition of partial melt (e.g., Kushiro, 1969). Melting of the metasomatized plums is favorable beneath the extensional axis region, which may generate the tholeiitic magmas from somewhat greater depths (e.g., $\geqslant 50 \mathrm{~km}$ ) than that suggested by anhydrous melting estimation. At both sides away from the Taiwan Strait, the plums are expected to gradually decrease. Magmas produced thereby become less silica-saturated and more alkalic as a result of greater depths of segregation and smaller degrees of melting.

The isotopic characteristics of SE China basalts can generally be explained by a binary mixing model, best illustrated by the $\mathrm{Pb}$ isotopes, according to which the CLM-derived plums are ascribed to a dominant EM 2 character $\left({ }^{206} \mathrm{~Pb} /{ }^{204} \mathrm{~Pb}>19.0\right)$ and the depleted asthenospheric matrix is represented by the ETO basalts. Variable mixing proportions of these two mantle components across the extension axis account for the distinct $\mathrm{Pb}$ and minor Sr and Nd isotopic variation in SE China basalts. The Outer Fujian tholeiites, for example, have the greatest contribution from the CLM-derived EM 2 component. By contrast, Inner Fujian basanites showing the least radiogenic $\mathrm{Pb}$ isotopic ratios overlap the field of ETO basalts (Fig. 6). This suggests that they were mainly derived from the asthenospheric source by small degrees of melting, with the involvement of much smaller amounts of the enriched plums. In the Penghu Islands, magmas probably resulted from a steeper lithosphere- 


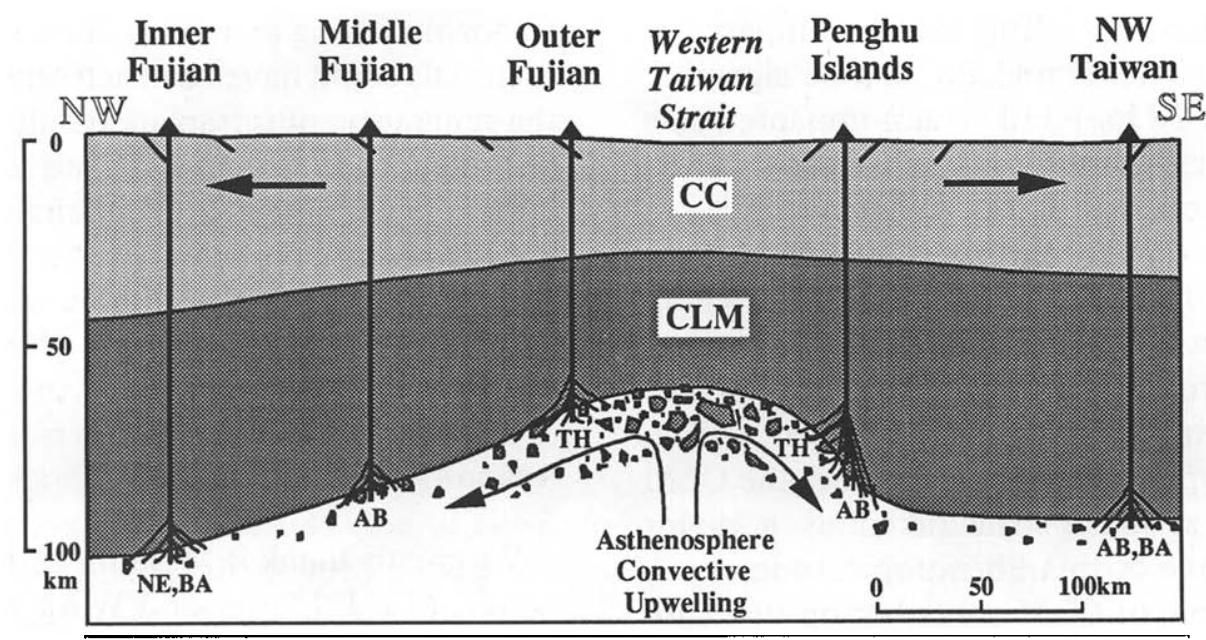

Fig. 7. Schematic SE China lithospheric profile during middle Miocene $(\sim 15-10 \mathrm{Ma})$. The passive extension in NW-SE direction (marked as black arrows) resulted in the lithosphere thinning and the asthenosphere upwelling. This interaction between lithosphere and asthenosphere created a plum-pudding type convecting mantle which could have served as magma source of the SE China basalts. $C C=$ continental crust; $C L M=$ continental lithospheric mantle.

asthenosphere boundary through different degrees of melting (Fig. 7). This explains why they have quite heterogeneous chemical compositions (from tholeiitic to alkali basaltic) but very uniform isotopic ratios.

\section{Broader implications for Cenozoic volcanism in eastern China}

In addition to various conditions during magma generation, chemical and isotopic characteristics of continental basalts are influenced by tectonic history of the source rock. It is especially true for the Cenozoic intraplate volcanism in eastern Asia, from where the lithospheric mantle has been widely considered as an important source for the basalts (Peng et al., 1986; Song et al., 1990; Basu et al., 1991; Tatsumoto and Nakamura, 1991; Tu et al., 1991; M. Zhang et al., 1991). There are two main tectonic processes which could have initiated the rifting environment necessary for generation of the intraplate basalts in eastern Asia. One is the collision between India and Eurasia. As suggested by Tapponnier et al. (1986), this collision created a tensional environment and reactivated old trans-litho- spheric faults in many places. The other is the Pacific plate subduction which may be particularly important to the "back-arc" intraplate volcanism in the Sea of Japan, Bohai Bay and NE China. During continental rifting, the lithospheric mantle could be mechanically stretched, thermally activated and eroded, and substantially involved in magma generation.

Models calling for mantle plume activity in this region (Nakamura et al., 1989; Tatsumi et al., 1990; Zhou and Zhu, 1992) encounter an absence of supportive geophysical observations. Seismic tomographic studies indicate that low-velocity zone detected under rifted regions in north China is between 60- and 180km depth (G.Y. Chen et al., 1991). A recent global tomographic model (Anderson et al., 1992) also reveals that beneath eastern Asia low velocities exist only in the uppermost 200 $\mathrm{km}$ of the mantle. Therefore, regional distribution pattern of the low-velocity zone in eastern China is rather consistent with the passive rifting model.

It has been well documented (Tu et al., 1989; Zartman et al., 1991; Tatsumoto et al., 1992) that all Cenozoic basalts in eastern China show consistently elevated ${ }^{208} \mathrm{~Pb} /{ }^{204} \mathrm{~Pb}$ (and some- 
what higher ${ }^{207} \mathrm{~Pb} /{ }^{204} \mathrm{~Pb}$ ) values compared to the NHRL. This Dupal Pb isotope signature $\left(\Delta^{208} \mathrm{~Pb}=+30\right.$ to +110$)$ is accompanied by a general increase in ${ }^{206} \mathrm{~Pb} /{ }^{204} \mathrm{~Pb}$ ratios $(16.6-$ 19.0) from north to south, across cratonic, circum-cratonic and oceanic tectonic domains. A Dupal-type region extending over $4000 \mathrm{~km}$ in eastern Asia can not have resulted solely from a northward transport or extension of the southern hemisphere Dupal field (Hart, 1984). If a mantle plume was not involved, the CLM should be seriously considered as a major mantle source of this $\mathrm{Pb}$ isotopic anomaly. A good example of CLM contribution to Cenozoic volcanism in NE China is the Quaternary ultrapotassic rocks from the Wudalianchi area, NE China (B.L. Liu et al., 1989; Basu et al., 1991; M. Zhang et al., 1991; Menzies et al., 1992; J.B. Zhang, 1992). These rocks have typical EM 1 isotopic compositions showing the most depleted $\mathrm{Pb}\left({ }^{206} \mathrm{~Pb} /{ }^{204} \mathrm{~Pb} \approx 16.5\right)$ and $\mathrm{Nd}$ $\left(\epsilon_{\mathrm{Nd}} \approx 12\right)$ isotopic ratios among the eastern China basalts, suggesting an activation of ancient metasomatized portion in the deeper CLM. Their spidergrams (M. Zhang et al., 1991; J.B. Zhang, 1992; B.M. Jahn, pers. commun., 1992) display minor $\mathrm{Nb}$ depletion $(\mathrm{Nb} /$ $\mathrm{La}=0.75 \pm 0.21)$. These combined chemical and isotopic characteristics could be interpreted as superposition of some Proterozoic intraplate metasomatic events over ancient subduction zone modification.

Paleozoic and early Mesozoic kimberlites have been reported in areas surrounding the Bohai Bay in the Sino-Korean Craton, eastern China (cf. Lu, 1991). Studies on some of these kimberlites (Lu, 1991) and their mantle xenoliths (Griffin et al., 1992) revealed that the lithosphere thickness around the Bohai Bay was more than $180 \mathrm{~km}$ in the Ordovician. The present lithosphere thickness in this extensional region, however, has been greatly reduced to $\sim 80 \mathrm{~km}$ as evidenced by geophysical data (G.Y. Chen et al., 1991). This removal of thick lithosphere may have also resulted from thermo-mechanical erosion as a part of the
Cenozoic rifting processes. The eroded CLM materials could have been actively involved in the generation of intraplate basalts around the Sea of Japan, Bohai Bay and northeastern China. These basalts are thus characterized by EM1-type isotopic anomaly (Tatsumoto and Nakamura, 1991) and display spatial chemical and isotopic variations (Nohda et al., 1991 ).

\section{Acknowledgements}

We greatly thank B.M. Jahn, U. Knittel, N.T. Arndt, M.F.J. Flower and W.M. McDonough for their valuable comments on various drafts of this paper. The discussions with $\mathrm{H}$. Cheng and $Y$. Tatsumi about magma segregation depths were helpful. Special thanks are due to Q.C. Fan for generously providing some critical Fujian samples and allowing us to quote his unpublished data. Editorial reviews of N.T. Arndt, M.A. Menzies and E. Nakamura were constructive. S.L. Chung is most grateful for the encouragement and support from Professor B.M. Jahn during his stay in Rennes which was sponsored by a post-doc research grant from CNRS (France) and NSC (Taiwan, R.O.C.). S.-s. Sun publishes with the permission of the executive director of Australian Geological Survey Organisation. The authors in Taipei were partially supported by the National Science Council (R.O.C.) research grant (NSC780202-M002-09/Chen ).

\section{References}

Amundsen, H.E.F., Griffin, W.L. and O'Reilly, S.Y., 1987. The lower crust and upper mantle beneath northwestern Spitsbergen: evidence from xenoliths and geophysics. Tectonophysics, 139: 169-185.

Anderson, D.L., Tanimoto, T. and Zhang, Y.-s., 1992. Plate tectonics and hotspots: the third dimension. Science, 256: 1645-1651.

Angelier, J., Bergerat, F., Chu, H.T., Juang, W.S. and Lu, C.Y., 1990. Paleostress analysis as a key to margin extension: the Penghu Islands, South China Sea. Tectonophysics, 183: 161-176.

Basu, A.R., Wang, J.W., Huang, W.K., Xie, G.H. and Tatsumoto, M., 1991. Major element, REE, and $\mathrm{Pb}, \mathrm{Nd}$ 
and $\mathrm{Sr}$ isotopic geochemistry of Cenozoic volcanic rocks of eastern China: implications for their origin from sub-oceanic type mantle reservoirs. Earth Planet. Sci. Lett., 105: 149-169.

BGMR (Bureau of Geology and Mineral Resources of Fujian Province), 1985. Regional geology of Fujian Province. Geol. Mem. Ser. 1, No. 4, Geological Publishing House, Beijing, 671 pp. (in Chinese, with 56 pp. of English abstract).

Brey, G.P. and Kohler, T.P., 1990. Geothermobarometry in four-phase lherzolites, Part II: New thermobarometers, and pratical assessment of existing thermobarometers. J. Petrol., 31: 1353-1380.

Chen, C-H., 1990. The igneous rocks of Taiwan. Cent. Geol. Surv., Taipei, Publ. No. 1, 137 pp. (in Chinese).

Chen, C-H., Chung, S.L. and Lee, C.Y., 1987. Genesis of Neogene continental margin alkali basalts and tholeiites in western Taiwan and the significance of highpressure megacrysts and lherzite inclusion. Acta Geol. Taiwan, 25: 111-132.

Chen, C-H., Chen, S., Chung, S.L., Huang, H.H., Lee, C.Y. and Lee, T., 1989. Spatial and temporal variations of Neogene continental basalts in Taiwan: $\mathrm{Nd}$ and $\mathrm{Sr}$ isotope and trace element constraints. IAVCEI (Int. Assoc. Volcanol. Chem. Earth's Inter.) Assem. on Continental Magmatism, Sante Fe, N.M., Abstr. Vol., p.49.

Chen, G.Y., Song, Z.H., An, C.Q., Cheng, L.H., Zhuang, Z., Fu, Z.W., Lu, Z.L. and Hu, J.F., 1991. Three-dimensional crust and upper mantle structure of the north China region. Acta Geophys. Sin., 34: 175-181.

Chen, J.C., 1973. Geochemistry of basalts from Penghu Islands. Proc. Geol. Soc. China, 16: 23-36.

Chi, W.R., Namson, J. and Suppe, J., 1981. Stratigraphic record of plate interactions in the Coastal Range of eastern Taiwan. Mem. Geol. Soc. China, 4: 155-195.

Chung, S.L., 1990. Geochemistry of megacrysts and xenoliths in alkali basalts from western Taiwan and implications for petrogenesis of the late Cenozoic intraplate basalts from southeastern China. Ph.D. Thesis, Institute of Geology, National Taiwan University, Taipei (in Chinese; unpublished).

Chung, S.L. and Sun, S.-s., 1992. A new genetic model for the East Taiwan Ophiolite and its implications for Dupal domains in the northern hemisphere. Earth Planet. Sci. Lett., 109: 133-145.

Chung, S.L., Chen, S.J., Lee, C.Y., Jahn, B.M., Chen, CH. and Lee, T., 1994. Geochemical and isotopic systematics of the late Cenozoic basalts in western Taiwan. (In preparation.)

Davis, P.M., 1991. Continental rift structures and dynamics with reference to teleseismic studies of the Rio Grande and East African rifts. Tectonophysics, 197: 309-325.

Falloon, T.J., Green, D.H., Harton, C.J. and Harris, K.L., 1988. Anhydrous partial melting of a fertile and depleted peridotite from 2 to $30 \mathrm{~kb}$ and application to basalt petrogenesis. J. Petrol., 29: 1257-1282.

Fan, Q.C. and Hooper, P.R., 1989. The mineral chemistry of ultramafic xenoliths of eastern China: implications for mantle composition and the paleogeotherms. J. Petrol., 30: 1117-1158.

Fan, Q.C. and Hooper, P.R., 1991. The Cenozoic basaltic rocks of eastern China: petrology and chemical composition. J. Petrol., 32: 765-810.

Frey, F.A., Garcia, M.O., Wise, W.S., Kennedy, A., Gurriet, $P$. and Albarède, F., 1991. The evolution of Mauna Kea Volcano, Hawaii: petrogenesis of tholeiitic and alkalic basalts. J. Geophys. Res., 96: 14347-14375.

Griffin, W.L., O'Reilly, S.Y. and Ryan, C.G., 1992. Composition and thermal structure of the lithosphere beneath South Africa, Siberia and China: proton microprobe studies. Abstr., Symp. on Cenozoic Volcanic Rocks and Deep-seated Xenoliths in China and its Environ, Beijing, September 8-10, 1992, pp. 65-66.

Hart, S.R., 1984. A large isotope anomaly in the Southern Hemisphere mantle. Nature (London), 309: 753-757.

Hickey-Vargas, R., 1991. Isotope characteristics of submarine lavas from the Philippine Sea: implications for the origin of arc and basin magmas of the Philippine tectonic plate. Earth Planet. Sci. Lett., 107: 290-304.

Jahn, B.M., 1986. Mid-ocean ridge or marginal basin origin of the East Taiwan Ophiolite: chemical and isotopic evidence. Contrib. Mineral. Petrol., 92: 194-206.

Jahn, B.M., Zhou, X.H. and Li, J.L., 1990. Formation and tectonic evolution of southeast China: isotopic and geochemical constraints. Tectonophysics, 183: 145160.

Juang, W.S., 1992. K-Ar dating and geochemical studies of Miocene basalts in western Taiwan. Handbk. Annu. Meet., Geol. Soc. China, Tainan, Taiwan, p. 88 (abstract).

Keller, G.R., Khan, M.A., Morgan, P., Wendlandt, R.F., Baldridge, W.S., Olsen, K.H., Prodehl, C. and Braile, L.W., 1991. A comparative study of the Rio Grande and Kenya rifts. Tectonophysics, 197: 355-371.

Klootwijk, C.T., Gee, J.S., Peirce, J.W., Smith, G.M. and McFadden, P.L., 1992. An early India-Asia conytact: paleomagmetic constraints from Ninetyeast Ridge, ODP Leg 121. Geology, 20: 395-398.

Kohler, T.P. and Brey, G.P., 1989. Calcium exchange between olivine and clinopyroxene calibrated as a geothermobarometer for natural peridotites from 2 to 60 $\mathrm{Kb}$ with applications. Geochim. Cosmochim. Acta, 54: 2375-2388.

KRISP (Kenya Rift International Seismic Project Working Party), 1991. Large-scale variation in lithospheric structure along and across the Kenya rift. Nature (London), 354: 223-227.

Kushiro, I., 1969. The system diopside-forsterite-silica with and without water at high pressures. Am. J. Sci., 267A: 269-294.

Le Maitre, R.W. (Editor), 1989. A Classification of Igneous Rocks and Glossary of Terms: Recommenda- 
tion of the IOU Subcommission on the Systematics of Igneous Rocks. Blackwell, Oxford, 193 pp.

Li, X.H., 1988. Geochemical study on the WanyangshanZhuguangshan granitoids and implications for the crustal evolution in South China. Ph.D. Thesis, Institute of Geochemistry, Guangzhou Branch, Academica Sinica, Guangzhou, $190 \mathrm{pp}$. (in Chinese).

Liao, Q.L, Wang, Z.M. and Qiu, T.X., 1987. Preliminary study of the crust and upper mantle in Fujian. In: Proc. Symp. on Geology and Seismology of the Taiwan Strait and its Coasts, Fuzhou. China Ocean Press, Beijing, pp. 269-271.

Lin, J.L., Fuller, M. and Zhang, W.Y., 1985. Preliminary Phanerozoic polar wander paths for the North and South China blocks. Nature (London), 313: 444-449.

Liu, B.L., Chen, Y.W. and Zhu, B.Q., 1989. Origin of Cenozoic basalts from Jinbohu, NE China and chemical characteristics of their mantle source: $\mathrm{Sr}-\mathrm{Pb}$ isotope and trace element evidence. Geochimica, pp. 919.

Liu, C.C. and Yen, T.P., 1975. Bouguer anomaly, surface elevation and crustal thickness in Taiwan. Petrol. Geol. Taiwan, 12: 97-108.

Lu, F.X. (Editor), 1991. Kimberlites and diamond exploration. Geol. Sci. Technol. Inform., Spec. Publ., Wuhan, $146 \mathrm{pp}$. (in Chinese).

Ma, X.Y. (Editor), 1987. The dynamics of continental lithosphere in China: a description book to the lithospheric dynamic map of China and adjacent seas. Geological Press, Beijing, 76 pp. (in Chinese).

MacDonald, G.A. and Katsura, T., 1964. Chemical composition of Hawaiian lavas. J. Petrol., 5: 82-133.

Mahoney, J.J., Natland, J.A., White, W.M., Poreda, R., Bloomer, S.H., Fisher, R.L. and Baxter, A.N., 1989. Isotopic and geochemical provinces of the western Indian Ocean spreading centers. J. Geophys. Res., 94: 4033-4052.

McDermott, F., Defant, M.J., Hawkesworth, C.J., Maury, R.C. and Joron, J.L., 1993. Isotope and trace element evidence for three component mixing in the genesis of North Luzon are lavas (Philippines). Contrib. Mineral. Petrol., 113: 9-23.

McKenzie, D. and Bickle, M.J., 1988. The volume and composition of melt generated by extension of the lithosphere. J. Petrol., 29: 625-679.

Menzies, M.A., Kyle, P.R., Jones, M. and Ingram, G., 1991. Enriched and depleted source components for tholeiitic and alkaline lavas from Zuni-Bandera, New Mexico: inferences about intraplate precesses and stratified lithosphere. J. Geophys. Res., 96: 1364513671.

Menzies, M.A., Fan, W.M., Baker, J., Thirlwall, M.F. and Zhang, M., 1992. The lower lithosphere of eastern China: on-craton/off-craton isotopic provinciality or recent recycling? Abstr., Symp. on Cenozoic Volcanic Rocks and Deep-seated Xenoliths in China and its En- viron, Beijing, September 8-10, 1992, pp. 85-88.

Metcalfe, I., 1990. Allochthonous terrane processes in Southeast Asia. Philos. Trans. R. Soc. London, Ser. A, 331: 625-640.

Nakamura, E., Campbell, I.H., McCulloch, M.T. and Sun, S.-s., 1989. Chemical geodynamics in a back-arc region around the Sea of Japan: implications for the genesis of alkaline basalts in Japan, Korea and China. J. Geophys. Res., 94: 4634-4654.

Nickel, K.G. and Green, D.H., 1985. Empirical geothermobarometry for garnet peridotites and implications for the nature of the lithosphere, kimberlites and diamonds. Earth Planet. Sci. Lett., 73: 158-170.

Nohda, S., Cheng, H. and Tatsumi, Y., 1991. Geochemical stratification in the upper mantle beneath NE China. Geophys. Res. Lett., 18: 97-100.

O'Reilly, S.Y. and Griffin, W.L., 1985. A xenolith-derived geotherm for southeastern Australia and its geophysical implications. Tectonophysics, 111: 41-63.

Peng, Z.C., Zartman, R.E., Futa, K. and Chen, D.G., 1986. $\mathrm{Pb}, \mathrm{Sr}$ and $\mathrm{Nd}$ isotopic systematics and chemical characteristics of Cenozoic basalts, eastern China. Chem. Geol. (Isot. Geosci. Sect.), 59: 3-33.

Perry, F.V., Baldridge, W.S. and DePaolo, D.J., 1988. Chemical and isotopic evidence for lithospheric thinning beneath the Rio Grande Rift. Nature (London), 332: 432-434.

Price, R.C., Gray, C.M., Wilson, R.E., Frey, F.A. and Taylor, S.R., 1991. The effect of weathering on rareearth element, $\mathrm{Y}$ and Ba abundances in Tertiary basalts from southeastern Australia. Chem. Geol., 93: 245-265.

Qi, J.Y. and Zhang, X.Q., 1985. Geochemistry of basalts and their mantle inclusions from Mt. Niutou, Fujian Province. Acta Petrol. Sin., 1: 1-13 (in Chinese).

Ru, K. and Piggot, J.D., 1986. Episodic rifting and subsidence in the South China Sea. Bull. Am. Assoc. Pet. Geol., 70: 1136-1155.

SCSIO-FOI (South China Sea Institute of Oceanology and Fujian Oceanic Institute), 1989. The investigation and study on petroleum geology and geophysics in the western Taiwan Strait. China Ocean Press, Beijing, 134 pp. (in Chinese).

Song, Y., Frey, F.A. and Zhi, X., 1990. Isotopic characteristics of Hannuoba basalts, eastern China: implications for their petrogenesis and the composition of subcontinental mantle. Chem. Geol., 85: 35-52.

Staudigel, H., Zindler, A., Hart, S.R., Leslie, T.M., Chen, C.-Y. and Clague, D., 1984. The isotopic systematics of a juvinile intraplate volcano: $\mathrm{Pb}, \mathrm{Nd}$, and $\mathrm{Sr}$ isotopic ratios of basalts from Loihi seamount, Hawaii. Earth Planet. Sci. Lett., 69: 13-29.

Sun, S.C., 1985. The Cenozoic tectonic evolution of offshore Taiwan. Energy, 10: 421-432.

Sun, S.-s., 1980. Lead isotopic study of young volcanic rocks from mid-ocean ridges, ocean islands and island arcs. Philos. Trans. R. Soc. London, Ser. A, 297: 409455. 
Sun, S.-s. and McDonough, W.F., 1989. Chemical and isotopic systematics of oceanic basalts: implications for mantle composition and processes. In: A.D. Sanders and M.J. Norry (Editors), Magmatism in the Ocean Basins. Geol. Soc. London, Spec. Publ., 42: 313-345.

Sun, S.-s., McDonough, W.F. and Ewart, A., 1989. A fourcomponent model for Eastern Australian basalts. In: R.W. Johnson (Editor), Intraplate Volcanism in Eastern Australia and New Zealand. Cambridge University Press, Sydney, N.S.W., pp. 333-347.

Sun, W.H. and Lai, Z.M., 1980. Petrochemical characteristics of Cenozoic volvanic rocks in Fujian province and its relationship to tectonics. Geochimica, 1: 134147 (in Chinese).

Suppe, J., 1981. Mechanics of mountain-building and metamorphism in Taiwan. Mem. Geol. Soc. China, 4: 67-90.

Tapponnier, P., Peltzer, G. and Armiro, R., 1986. On the mechanics of the collision between India and Asia. In: M.P. Coward and A.C. Ries (Editors), Collision Tectonics. Geol. Soc. London, Spec. Publ., 19: 115-157.

Tatsumi, Y. and Kimura, N., 1991. Secular variation of basalt chemistry in the Kenya Rift: evidence for the pulsing of asthenospheric upwelling. Earth Planet. Sci. Lett., 104: 99-113.

Tatsumi, Y., Maruyama, S. and Nohda, S., 1990. Mechanism of backarc opening in the Japan Sea: role of asthenospheric injection. Tectonophysics, 181:299-306.

Tatsumoto, M. and Nakamura, Y., 1991. Dupal anomaly in the Sea of Japan: $\mathrm{Pb}, \mathrm{Nd}$, and $\mathrm{Sr}$ isotopic variations at the eastern Eurasian continental margin. Geochim. Cosmochim. Acta, 55: 3697-3708.

Tatsumoto, M., Basu, A.R., Huang, W.K., Wang, J.W. and $\mathrm{Xie}, \mathrm{G} . \mathrm{H} .$, 1992. $^{\mathrm{Sr}}$, Nd and $\mathrm{Pb}$ isotopes of ultramafic xenoliths in volcanic rocks of eastern China: enriched components EM1 and EM2 in subcontinental lithosphere. Earth Planet. Sci. Lett., 113: 107-128.

Teng, L.S., 1990. Geotectonic evolution of late Cenozoic arc-continent collision in Taiwan. Tectonophysics, 183: 57-76.

Teng, L.S., Wang, Y., Tang, C.H., Huang, C.Y., Huang, T.C., Yu, M.S. and Ke, A., 1991. Tectonic aspect of the Paleogene depositional basin of northern Taiwan. Proc. Geol. Soc. China, 34: 313-336.

Tu, K., Flower, M.F.J., Xie, G.H., Carlson, R.W., Wang, Q. and Zhang, M., 1989. Lead isotopic data for Cenozoic basalts from eastern China: evidence for cratonic and circum-cratonic mantle domains. Abstr. 28th Int. Geol. Congr., Washington, D.C., 3: 260-261.

Tu, K., Flower, M.F.J., Carlson, R.W., Zhang, M. and Xie, G.H., 1991. Sr, $\mathrm{Nd}$, and $\mathrm{Pb}$ isotopic compositions of Hainan basalts (south China): implications for a subcontinental lithosphere Dupal source. Geology, 19: 567-569.

Tu, K., Flower, M.F.J., Carlson, R.W., Xie, G.H., Chen, C.-Y. and Zhang, M., 1992. Magmatism in the South
China Basin, 1. Isotopic and trace element evidence for an endogenous Dupal mantle component. Chem. Geol., 97: 47-63.

Wan, T.F., Tong, Y.F. and Zheng, W.W., 1989. Thermal structure of the lithosphere in Fujian, China. J. Geophys. Res., 94: 1888-1894.

Wang, Y., 1987. Continental margin rifting and Cenozoic tectonics around Taiwan. Mem. Geol. Soc. China, 9: 227-240.

Wells, P.R.A., 1977. Pyroxene thermometry in simple and complex systems. Contrib. Mineral. Petrol., 62: 129139.

Wendlandt, R.F. and Morgan, P., 1982. Lithospheric thinning associated with rifting in east Africa. Nature (London), 298: 734-736.

Wood, B.J. and Banno, S., 1973. Garnet-orthopyroxene and orthopyroxene-clinopyroxene relationships in simple and complex systems. Contrib. Mineral. Petrol., 42: 109-124.

Zartman, R.E., Futa, K. and Peng, Z.C., 1991. A comparison of $\mathrm{Sr}-\mathrm{Nd}-\mathrm{Pb}$ isotopes in young and old continental lithospheric mantle: Patagonia and eastern China. Aust. J. Earth Sci., 38: 545-557.

Zhang, J.B., 1992. Characteristics of the ultrapotassic rocks in NE China and implication for regional mantle geochemistry. Ph.D. Thesis, Institute of Geology, Chinese Academy of Sciences, Beijing (in Chinese; unpublished).

Zhang, J.B. and Chen, D.G., 1992. The geochemistry of basalts from Longhai and Mingxi areas in Fujian Province. In: R.X. Liu (Editor), Geochronology and Geochemistry of the Cenozoic Volcanic Rocks in China. Seismic Press, Beijing, pp. 298-319 (in Chinese).

Zhang, M., Menzies, M.A., Suddaby, P. and Thirlwall, M.F., 1991. EM1 signature from within the post-Archean subcontinental lithospheric mantle: isotopic evidence from the potassic volcanic rocks in NE China. Geochem. J., 25: 387-398.

Zhang, M., Flower, M.F.J. and Shimizu, N., 1992. Diversification of continental lithospheric mantle: trace element differentiation in mantle diopsides. Eos (Trans. Am. Geophys. Union), Spring Meet. Suppl., 73(14): 324 (abstract).

Zhang, R.Y. and Cong, B.L., 1987. The Cenozoic volcanic rocks and their bearing ultramafic xenoliths in southeastern China. In: M.L. Er and D.S. Zhao (Editors), Cenozoic Basalts and Mantle-derived Xenoliths in Eastern China. Science Press, Beijing, pp. 349-475 (in Chinese),

Zhao, H.L., 1990. Neogene-Quaternary continental rifting volcanism and deep proceses in the southeast coast of China. China Geosciences University Press, Wuhan, 163 pp. (in Chinese).

Zhou, X.H. and O'Nions, R.K., 1986. Pb-Nd-Sr systematics of xenoliths from east China. Terra Cognita, 6: 244 (abstract). 
Zhou, X.H. and Zhu, B.Q., 1992. Isotopic systematics of Cenozoic basalts in eastern China and classification of the mantle chemistry. In: R.X. Liu (Editor), Geochronology and Geochemistry of the Cenozoic Volcanic Rocks in China. Seismic Press, Beijing, pp. 366-391 (in Chinese).

Zhou, X.H., Zhu, B.Q., Liu, R.X. and Chen, W.J., 1988. Cenozoic basaltic rocks in eastern China. In: J.D. Macdougall (Editor), Continental Flood Basalts. Kluwer, Dordrecht, pp. 311-330.

Zhu, B.Q., Wang, H.F., Zou, L.P. and Yi, W., 1992. Geo- chemical features of Cenozoic basalts from ZhejiangFujian areas and implications for geochemical mapping of mantle. Abstr., Symp. on Cenozoic Volcanic Rocks and Deep-seated Xenoliths in China and its Environ, Beijing, September 8-10, 1992, pp. 111-112.

Zindler, A. and Hart, S.R., 1986. Chemical geodynamics. Annu. Rev. Earth Planet. Sci., 14: 493-571.

Zindler, A., Staudigel, H. and Batiza, R., 1984. Isotope and trace geochemistry of young Pacific seamounts: implications for the scale of upper mantle heterogeneity. Earth Planet. Sci. Lett., 70: 175-195. 